\title{
Effect of Inorganic Fertilizers and Neem-cake on Growth and Yield of Pea Crop (Pisum sativum L.)
}

\author{
Balveer Singh Khangarot*, Narendera Swaroop and Tarence Thomas \\ Department of Soil Science and Agricultural Chemistry, Sam Higginbottom University of \\ Agriculture, Technology and Sciences, Prayagraj, U.P. India \\ *Corresponding author
}

\section{Keywords}

Soil parameters, Inorganic fertilizers, NPK levels, Neem cake, Field pea

Article Info

Accepted: 12 October 2020 Available Online: 10 November 2020

\section{A B S T R A C T}

The present investigation was carried out at Research farm, Department of Soil Science and Agricultural Chemistry, Naini Agricultural Institute, SHUATS, Allahabad (U.P.) during the Rabi season of 2019-20 with the objective to response of different levels of N P $\mathrm{K}$ and Neem cake on soil health, growth and yield attributes of Field pea (Pisum sativum L.). The experiment was laid out in a Randomized Block Design with nine treatment combinations, consisting of three N P K levels $(0,50$ and $100 \%)$ and Neem cake $(0,50$ and 100\%). It was observed that for postharvest, treatment $\mathrm{T}_{8}$ (i.e. @ $\mathrm{n} 40 \mathrm{~kg}+\mathrm{p} @ 50 \mathrm{~kg}+\mathrm{k} @$ 40kg and neem cake @2.5 q ha ${ }^{-1}$ )was best in terms growth parameters in maximum plant height $(86.54 \mathrm{~cm})$,number of leaves $(74.59 \mathrm{~cm})$, number of branches $(17.31)$, number of pods per plant (17.93) and total green pod yield was highest i.e. $\left(71.47 \mathrm{qha}^{-1}\right)$, maximum gross return of (Rs. 107205.00) and net profit was (Rs. 76417.00) with cost benefit ratio (B:C) (1:2.48). However treatment $\mathrm{T}_{6}$ (i.e. N @40kg + p@ 50kg + k @ 40kg and neem cake @ $\left.0 \mathrm{q} \mathrm{ha}^{-1}\right)$ was best in terms economic parameters was found maximum cost benefit ratio of (1: 2.99), showed medium results in growth parameters soil properties with a highest net returns it was best and has suitable treatment combination regarding all aspects.

\section{Introduction}

Pulses are important source of dietary protein and have unique ability of maintaining and restoring soil fertility through biological nitrogen fixation as well as addition of ample number of residues to the soil. Pulse crops leave behind reasonable quantity of nitrogen in soil to the extent of $30 \mathrm{~kg} \mathrm{ha}^{-1}$. India has a major world's crop area under pulses and one fourth of the total production. Pulse crops offer and stable source of protein in vegetarian diet of masses. Pulses add 0.8 to
1.5 tonnes of organic matter to the soil in the form of their roots left after harvesting of the crops, on an average, one-hectare crop adds 15 to $30 \mathrm{~kg}$ nitrogen in readily available form (Singh, 2001).

Legumes have been recognized as an important component of any cropping system and as a low input approach towards improvement of soil fertility. Peas are now grown throughout the world and are consumed in both fresh and dried conditions. It is widely cultivated in temperate regions for 
its fresh green seed. Peas are an excellent human food (Kakar et al., 2002), either eaten as a vegetable or used in preparation of soup. The peas are full of nutrition because its grain is rich in protein, complex carbohydrates, vitamins, minerals, dietary fibers and antioxidant compounds (Bhatt et al., 2013).

In Gujarat, it is cultivated in 2.09 lakh hectares with an annual production of 1.14 lakh metric tonnes leading to average productivity of $546 \mathrm{~kg} \mathrm{ha}^{-1}$ (Anonymous, 2011). Peas (Pisum sativum L.) is one of the most important Rabi season Pulses crop of Uttar Pradesh. Total production of pulse, reported 2012-2013(April/ May) will be at 17.3 million tonnes. In which from them pea will be covered in production 3744.84 tonnes) (FAO stat, 2012).

\section{Materials and Methods}

The experiment was carried out at the research farm of Soil Science and Agricultural Chemistry Department (SSAC), Sam Higginbottom University of Agriculture, Technology and Sciences, Allahabad (UP), during Rabi season of November 2019 March 2020. The experiment was conducted in a Randomized Block Design (RBD) with three levels of inorganic fertilizers $\mathrm{N}, \mathrm{P}, \mathrm{K}$, and Neem cake $(0,50,100 \%$ dosage $)$ respectively, the treatments were replicated into three time dividing the experimental area into twenty-seven plots (Table 1).

\section{Pre- and post-harvest observations}

\section{Plant height (cm)}

Height of crop plants under different treatments was recorded at 30, 60 and 90 days after sowing. For these three plants were randomly selected from each plot and tagged for observation to be recorded. Height of plant in $\mathrm{cm}$ was from ground level up to the base of the last fully opened leaf of the main shoot.

\section{Pods length}

The number pods were collected from three tagged plants from each plot was counted and average pods length per plant was calculated.

\section{No. of pods per plant}

The number pods were collected from three tagged plants from each plot was counted and average number of pods per plant was calculated.

\section{Green pod yield $\left(\mathrm{q} \mathrm{ha}^{-1}\right)$}

The pod yield from the net plot area was recorded in $\mathrm{kg} \mathrm{plot}^{-1}$ and figure converted into q/ha.

\section{Results and Discussion}

\section{Growth parameters}

\section{Plant height (cm)}

The data presented in table 2 and depicted in fig. 1 clearly shows the response of plant height of pea recorded at 30 DAS, 45 DAS and 60 DAS as influenced by different levels N P K and Neem cake seed inoculation. The plant height of pea was found to be increased significantly with the increase in levels of N P $\mathrm{K}$ and Neem cake seed inoculation.

The maximum plant height was recorded as $34.38 \mathrm{~cm}, 64.40 \mathrm{~cm}$ and $86.54 \mathrm{~cm}$ in $\mathrm{T}_{8} \mathrm{~N}_{40}$ $\mathrm{P}_{50} \mathrm{~K}_{40}+$ Neem cake @ 2.5q ha ${ }^{-1}$ ) at 30 DAS, 60 DAS and 90 DAS respectively and the minimum plant height was recorded as 18.63 $\mathrm{cm}, 43.63 \mathrm{~cm}$ and $69.16 \mathrm{~cm}$ in $\mathrm{T}_{0}$ (control) at 30 DAS, 60 DAS and 90 DAS respectively. Increase in plant height due to increase in $\mathrm{N} \mathrm{P}$ $\mathrm{K}$ and Neem cake fertilizers may be due to 
adequate supply of nutrients which in turn helps in vigorous vegetative growth of plants and subsequently increase the plant through cell elongation, cell division, photosynthesis and turbidity of plant cell. The increase in nodulation and nitrogen fixation leads to more plant height. Similar findings were reported by Singh et al., (2011) and Jat et al., (2012).

\section{Number of Leaves per plant}

The data presented in table 2 and depicted in fig. 2 clearly shows the response of number of leaves plant ${ }^{-1}$ of pea recorded at 30 DAS, 60 DAS and 90 DAS as influenced by different levels N P K and Neem cake seed inoculation. The number of leaves plant ${ }^{-1}$ of pea was found to be increased significantly with the increase in levels of $\mathrm{N} \mathrm{P} \mathrm{K} \mathrm{and} \mathrm{Neem} \mathrm{cake}$ seed inoculation.

The maximum number of leaves was recorded as 14.57, 45.06 and 74.59 in $\mathrm{T}_{8}\left(\mathrm{~N}_{40} \mathrm{P}_{50} \mathrm{~K}_{40}+\right.$ Neem cake @ 2.5q ha ${ }^{-1}$ ) at 30 DAS, 60 DAS and 90 DAS respectively and the minimum number of leaves were recorded as 9.33, 16.63 and 45.83 in $\mathrm{T}_{0}$ (control) at $30 \mathrm{DAS}, 60$ DAS and 90 DAS respectively.

Increase in number of leaves may be due to adequate nutrients supply which enhanced the vegetative growth of plant and subsequently the number of leaves. Similar findings were reported by Khan et al., (2017) and Shete et al., (2010).

\section{Yield and yield attributes}

\section{Number of pods per plant}

The data presented in table 2 and depicted in fig. 3 clearly shows the response of number of pods plant $^{-1}$ of pea recorded as influenced by different levels N P K and Neem cake seed inoculation.

The number of pods plant ${ }^{-1}$ of pea was found to be increased significantly with the increase in levels of N P K and Neem cake seed inoculation. The maximum number of pods was recorded as 17.93 in $\mathrm{T}_{8}\left(\mathrm{~N}_{40} \mathrm{P}_{50} \mathrm{~K}_{40}+\right.$ Neem cake@2.5q ha ${ }^{-1}$ ) and the minimum number of pods were recorded as 8.33 in $\mathrm{T}_{0}$ (control).

Increased in number of pods may be due to adequate availability of nutrients during reproductive stage of crop results in the formation of more pods. Similar results were also reported by Datt et al., (2013) and Hussain et al., (2014).

Table.1 Treatment combinations

\begin{tabular}{|c|c|}
\hline Treatment & Treatment combination \\
\hline $\mathbf{T}_{\mathbf{0}}$ & Control \\
\hline $\mathbf{T}_{1}$ & $@ 0 \%(\mathrm{~N}, \mathrm{P}, \mathrm{K})+$ @ $50 \%$ Neem cake \\
\hline $\mathbf{T}_{2}$ & $@ 0 \%(\mathrm{~N}, \mathrm{P}, \mathrm{K})+$ @ $100 \%$ Neem cake \\
\hline $\mathbf{T}_{\mathbf{3}}$ & @50\%(N,P,K) + @ $0 \%$ Neem cake \\
\hline $\mathbf{T}_{4}$ & @50\%(N,P,K)+ @ $50 \%$ Neem cake \\
\hline $\mathbf{T}_{5}$ & @ 50\%(N,P,K) + @ $100 \%$ Neem cake \\
\hline $\mathbf{T}_{6}$ & @100\%(N,P,K)+ @ $0 \%$ Neem cake \\
\hline $\mathbf{T}_{7}$ & @ 100\%(N,P,K) + @ $50 \%$ Neem cake \\
\hline $\mathbf{T}_{8}$ & @ 100\%(N,P,K) + @ $100 \%$ Neem cake \\
\hline
\end{tabular}


Table.2 Effect of different levels of N P K and Neem cake on plant height, No. of leaves per plant, No. of pods per plant and green pod yield

\begin{tabular}{|c|c|c|c|c|c|c|c|c|}
\hline \multirow[t]{2}{*}{ Treatment } & \multicolumn{3}{|c|}{ Plant height (cm) } & \multicolumn{3}{|c|}{ No. of leaves per plant } & \multirow{2}{*}{$\begin{array}{c}\text { No. of pods } \\
\text { per plant }\end{array}$} & \multirow{2}{*}{$\begin{array}{l}\text { green pod } \\
\text { yield }\left(q \text { ha }^{-1}\right)\end{array}$} \\
\hline & 30 Days & 60 Days & 90 Days & 30 Days & 60 Days & 90 Days & & \\
\hline $\mathbf{T}_{\mathbf{0}}$ & 18.63 & 43.63 & 69.16 & 9.33 & 16.63 & 45.83 & 8.33 & 49.27 \\
\hline $\mathbf{T}_{1}$ & 21.17 & 45.37 & 72.09 & 10.32 & 17.67 & 49.70 & 9.42 & 51.27 \\
\hline $\mathbf{T}_{2}$ & 23.38 & 47.79 & 74.38 & 10.82 & 19.80 & 55.79 & 11.00 & 54.27 \\
\hline $\mathbf{T}_{\mathbf{3}}$ & 24.73 & 51.19 & 76.80 & 11.66 & 23.63 & 60.02 & 12.24 & 57.31 \\
\hline $\mathbf{T}_{4}$ & 26.37 & 53.71 & 78.70 & 11.93 & 28.87 & 66.08 & 13.52 & 59.73 \\
\hline $\mathbf{T}_{5}$ & 28.80 & 55.78 & 80.06 & 12.21 & 32.30 & 68.47 & 14.56 & 62.18 \\
\hline $\mathbf{T}_{6}$ & 30.56 & 58.07 & 82.22 & 12.78 & 37.66 & 71.66 & 15.70 & 65.33 \\
\hline $\mathbf{T}_{7}$ & 33.22 & 61.19 & 83.56 & 13.83 & 42.13 & 73.42 & 16.80 & 68.00 \\
\hline $\mathbf{T}_{8}$ & 34.38 & 64.40 & 86.54 & 14.57 & 45.06 & 74.59 & 17.93 & 71.47 \\
\hline F-test & S & S & S & S & S & S & $\mathrm{S}$ & S \\
\hline SE. d & 0.325 & 0.276 & 0.277 & 0.18 & 0.42 & 0.39 & 0.12 & 1.05 \\
\hline $\begin{array}{c}\text { C.D. }(P= \\
0.05)\end{array}$ & 0.689 & 0.585 & 0.589 & 0.38 & 0.90 & 0.83 & 0.24 & 2.22 \\
\hline
\end{tabular}




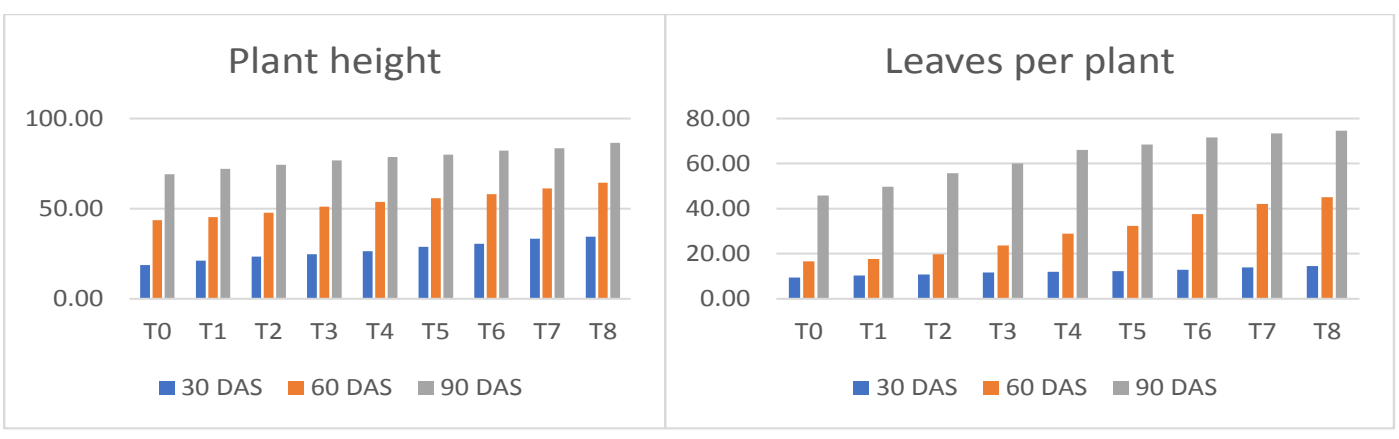

Fig: 1

Fig : 2

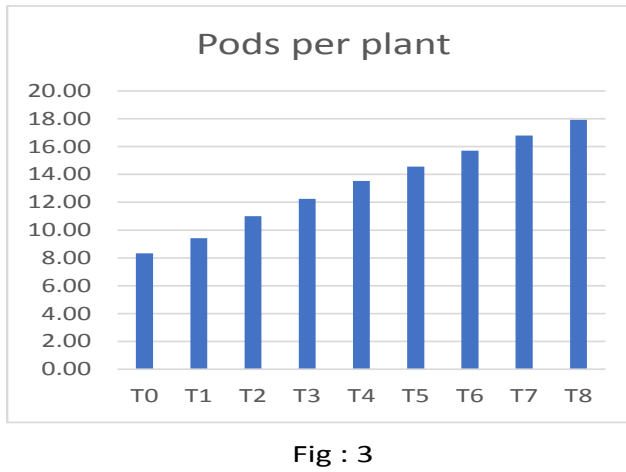

Green pod yield (q ha $\left.{ }^{-1}\right)$

Table 2 and fig. 4 shows the green pod yield ( $\mathrm{q} \mathrm{ha}{ }^{-1}$ ) as influenced by $\mathrm{N} \mathrm{P} \mathrm{K}$, and neem cake. The number of pods plant ${ }^{-1}$ of pea was found to be increased significantly with the increase in levels of N P K and neem cake seed inoculation. The highest green pod yield was recorded as 71.47 in $\mathrm{T}_{8}\left(\mathrm{~N}_{40} \mathrm{P}_{50} \mathrm{~K}_{40}+\right.$ Neem cake@2.5q ha ${ }^{-1}$ ) and the minimum green pod yield was recorded as 49.27 in $\mathrm{T}_{0}$ (control).Application of full doses of inorganic fertilizers along with the neem cake has given the good results regarding Green pod yield. Similar findings were reported by Dhruwe et al., (2017) and Prasad and Prasad (2003).

In conclusion the treatment $\mathrm{T}_{8}$ (i.e. @ $\mathrm{N} 40 \mathrm{~kg}$ +P@50kg+K@40kg and neem cake@2.5 $\mathrm{q} \mathrm{ha}^{-1}$ ) was best in terms growth parameters in maximum plant height $(86.54 \mathrm{~cm})$,Number of leaves $(74.59 \mathrm{~cm})$, Number of branches (17.31), number of pods per plant (17.93) and total green pod yield was highest i.e. (71.47 $\left.\mathrm{qha}^{-1}\right)$, maximum gross return of (107205.00) and net profit was (76417.00) with cost benefit ratio $(\mathrm{C}: \mathrm{B}) \quad(1: 2.48)$. However Treatment $\mathrm{T}_{6}$ (i.e. N@40kg + P@50kg + K@ $40 \mathrm{~kg}$ and neem cake@0 q ha ${ }^{-1}$ )was best in terms economic parameters was found maximum cost benefit ratio of (1: 2.99), showed medium results in growth parameters soil properties with a highest net returns it was best and has suitable treatment combination regarding all aspects. Since the results were based on one-year experimental data. It is suggested that the further work could be carried out for more than one season.

\section{References}

Anonymous (2011).Ministry of Agricultural, Government of India.

Bhat, T. A., Gupta, M., Ganai, M. A., Ahanger, R., and Bhat, A. H. (2013).Yield, soil health and nutrient utilization of field pea (Pisum sativum 
L.) as affected by phosphorus and biofertilizers under subtropical conditions of Jammu. International Journal of Modern Plant\&Animal Sciences, 1(1):1-8.

Datt, N., Dubey, Y. P. and Chaudhary, R. (2013). Studies on impact of organic, inorganic and integrated use of nutrients on symbiotic parameters, yield, quality of frenchbean (Phaseolus vulgaris L.) vis-à-vis soil properties of an acid alfisol. African Journal of Agricultural Research. 8: 2645-2654.

Dharwe, D. S., Dixit, H. C., Dotaniya, C. K., Khandagle, A., Mohbe, S. and Doutaniya, R. K. (2019).Effect of phosphorus and sulphur on the yield \& nutrient content of green gram. International Journal of Chemical Studies; 7(2): 01-05.

Hussain, F., Baloch, S. K., Sanaullah, Y. Y. and Bashir, W. (2014). Growth and Yield Response of Mongbean (Vigna radiata L.) to Different Levels of Potassium. Persian Gulf Crop Protection, 3(4): 49-53.

Jat, S. L., Prasad, K. and Parihar, C. M. (2012). Effect of organic manuring on productivity and economics of summer mungbean. Annals Agril. Res. (New Series), 33(1\&2): 17-20.
Kakar, A., Saleem, M., Shah, R. and Shah, Q., (2002) Growth and Marketable Pod Performance of Pea (Pisum sativum L.) under Varying Levels of NPK Fertilizers. Asian Journal of plant science, Number 5: 532-534.

Prasad, K. and Prasad, R. (2003). Effect of varieties and sulphur on yield and yield attributes of field pea (Pisum sativum var. arvense). Crop Research (Hisar); 25(3): 419-422.

Shete, P. G., Thanki, J. D., Baviskar, V. S. and Bhoye, K. P. (2011). Yield, nutrient uptake and economics of green gram as influenced by land configuration, inorganic fertilizers and FYM levels. Green Farming, 2: 425-427.

Singh, C. (2001). Modern techniques of raising field crops. IBH publishing company Pvt. Ltd., New-Delhi. Pp. 194-204.

Singh., R.N., Prasad, S.S., Singh, S.S. and Kumar, V.K.P. (2011). Effect of Integrated nutrient management on soil fertility, nutrient uptake and yield of rice-pea cropping system on an upland acid soil of Jharkhand. Journal of the Indian society of soil science, 59(2): 158-163.

\section{How to cite this article:}

Balveer Singh Khangarot, Narendera Swaroop and Tarence Thomas. 2020. Effect of Inorganic Fertilizers and Neem-cake on Growth and Yield of Pea Crop (Pisum sativum L.). Int.J.Curr.Microbiol.App.Sci. 9(11): 1718-1723. doi: https://doi.org/10.20546/ijcmas.2020.911.204 